as agriculture is concerned, it is the function of O.E.C.D. to promote the transformation of agricultural policies to meet changes in the position of agriculture within and between countries".

This and much other information on the work of the Organization in this field is contained in an article, "Agriculture in an Industrigl Economy", contributed by the Directorate for Agriculture, O.E.C.D., Paris (Span, 8, No. $3 ;$ 1965. Shell International Chemical Co., Ltd. Shell Centre, London, S.E.1). Span is an attractive and extremely well-presented magazine, published three times a year, and this particular issue contains a number of articles by different authors, the subjects ranging from pesticides, agricultural extension in the United States, a modern dairy farm in Thailand, Chinese market gardening in Malaya, urbanization and filariasis, tsetse eradication in Uganda, to the work of the Indian Agricultural Research Institute, which in 1965 celebrated its Diamond Jubilee.

Other interests and activities of the O.E.C.D. are chronicled regularly in the bi-monthly magazine, The O.E.C.D. Observer (in French and English). In a recent issue (No. 18; October 1965. O.E.C.D. Information Service, Château de la Muette, Paris), subjects dealt with are, inter alia: the high-level meeting of the O.E.C.D. development assistance committee; international payments; housing construction policies and techniques in Switzerland; a development plan for the Mediterranean coast of France; agriculture as a positive force in the growth process; and O.E.C.D. experience in efficient use of resources for school building. The Organization is responsible for many other publications covering a wide range of topics, as a list of recent titles in this issue makes clear. The new titles are: "Fish Handling and Preservation"; "Women Workers, Working Hours and Services"; "Wages and Labour Mobility"; "Teaching Physics Today"; and "International Standardization of Fruit and Vegetables", all being evidence of the practical manner in which the fundamental aims of the O.E.C.D. are being furthered and realized.

\section{Scientific Research in France}

Le Progrès Scientifique (No. 89; October 1965) contains a broad outline of the fifth Plan for Scientifie and Technical Research in France (1966-70), on which 3,600 million francs are to be expended, with 600 million francs for development. This includes all expenditure on funda. mental or applied research not under the military or space programmes or on the Atomic Energy Commission. 2,000 million francs are provided for space research, of which 450 million francs are for the European programme. Of the 3,600 million francs, 1,254 million francs are for physics, 590 million francs for biology and medicine, 400 million francs for chemistry, 390 million franes for agricultural research, 315 million francs for mathematics, 284 million francs for the sciences of the Earth, water and atmosphere, 150 million francs for oceanography, 120 million francs for the human sciences, and 162 million francs for construction, public works, urban studies. Some 43,350 research workers and technicians were available in 1963 , of whom 11,180 were in the natural and exact sciences, 19,160 in engineering, 8,410 in medicine and pharmacy, and 4,600 in the human sciences. Of the total, 16,530 were in higher education, 17,350 in professional and non-profit institutions, 4,310 in the Centre for Research in Nuclear Science, 2,540 in the Prime Minister's or Defence Ministry, and 2,620 in other technical ministries. The total is expected to increase by 35,000 during the period.

\section{The Netherlands Delta Plan}

SINCE time immemorial, the delta area lying southwest of Rotterdam in The Netherlands has been a 'halfopen door' through which the North Sea, in its stormier moods, has poured, inundating towns and villages, washing away precious topsoil and choking the land with a surfeit of salt. The tragic floods of 1953 , when more than 1,800 people lost their lives, 72,000 people had to flee from their homes south of Rottirdam, 800 miles of dykes were wrecked, 500,000 acres of land overrun, some 200,000 animals destroyed on Dutch farms, to say nothing of 10,000 houses, schools and churches destroyed, all taught a grim lesson. Shortly after this great disaster, what was known as the Delta Commission was formed in The Hague, its task to find a practical means of beating these terrible incursions of the North Sea for ever. One project was to raise the level of existing sea dykes; an alternative was the imaginative scheme of damming up the sea arms of the delta altogether. The Dutch have a fanatical and historical enthusiasm for land reclamation, and it was this second scheme that was recommended by the Commission, adopted by the Minister of Transport and Waterways, eventually approved by the Dutch Parliament, and consolidated under the Delta Act. The Delta Plan, as it is known, is undoubtedly one of the outstanding civil engineering ventures of this or, for that matter, any other age; it is estimated that it will take 25 years to complete; it will shorten the country's coastline by more than 400 miles, at an estimated cost of some $£ 250$ million.

In a strikingly illustrated article entitled "Against the Sea" (Esso Magazine, 4, 14; Autumn 1965. Esso Petroleum Co., Ltd., London, S.W.1), some details are given of this ambitious undertaking, including a map of the Delta Plan, giving the dates of starting and completing the major projects. The seven main constructions are Haringvliet, between Voorne and Goeree (1957-69); Brouwershavense Gat, between Goeree and Schouwen (1962-72); Oosterschelde, between Schouwen and Noord Beveland (1965-78); Veerse Gat, between Noord Beveland and Walcheren (1956-61); Zandkreek, between Noord Beveland and Zuid Beveland (1958-60); Grevelingen, between Overflakkee and Duiveland (1958-64); and Volkerak, between Hoeksche Waard and Overflakkee (1957-67); the years in parentheses are starting and finishing dates. The dams in the Haringvliet, Brouwershavense Gat and Oosterschelde are all major sea walls, the last-mentioned being the longest and heaviest dam in the whole scheme. The Haringvliet is the estuary through which more than half the waters of the Rhine and the Meuse empty into the North Sea. The Dutch want to hold and store as much of this water as possible in large fresh-water lakes, which will be constructed when the Delta Plan is complete, but at the same time they want to control the efflux of surplus water into the North Sea by means of seventeen sluices, each $185 \mathrm{ft}$. wide.

The Delta Plan will eventually secure the safety of the existing land; it will combat salination of rivers and adjoining channels, thus increasing agricultural production. The islands of the Delta will no longer be isolated; new roads will run on top of the new dykes, providing fast links with Belgium, Rotterdam and towns beyond in The Netherlands. A new natural playground will be created in this region, a country of wooded lakes and sandy beaches, an added attraction to tourists. The one disadvantage of this Delta Plan is that with the exclusion of the sea, once it is completed, the fisheries, oyster and mussel beds, so long characteristic of Zeeland, will disappear; but, it is argued, this is perhaps a small price to pay for beating the destructive power of the North Sea for ever in this enterprising country.

\section{Research in Chemical Information}

According to Scientific Information Notes (7, No. 5; October-November 1965), the National Bureau of Standards, in connexion with the Chemical Information Programme of the National Science Foundation, is to investigate fragmentation codes for preparing indexes of chemical structures, and searching techniques for specific and generic chemical structures represented as connexion 